\title{
Ján DUPLÁK, Michal HATALA* \\ COMPREHENSIVE EXPRESSION OF DURABILITY FOR THE SELECTED CUTTING TOOLS IN COMPARISON WITH STANDARD ISO 3685
}

\author{
KOMPLEXNÍ VYJÁDŘENÍ TRVANLIOSTI PRO VYBRANÉ ŘEZNÉ NÁSTROJE \\ V POROVNÁSNÍ S NORMOU ISO 3685
}

\begin{abstract}
Durability of cutting tool defines lifetime of this cutting tool and it determines its suitability for select technological operation. Technical science defines a lot of different factors, that they may be cause of shorter cutting tool lifetime. Some types of cutting materials are defined by means of descriptions in standards ISO, some types by means of catalogues from the manufacturer. There are a lot of types of cutting materials they have not been defined theirs properties exactly yet and theirs properties have to be defined on experiments. There is a presumption that descriptions in standards ISO are not correct and these standards have to be examined and verified, because that this fact have to be confirmed or disproved. Accuracy and completeness technical standards ISO are very important part quality of manufacturing. Only correct standards ISO should be used like instruction, or tool for manufacturing process of companies. The article describes process how to define and analytically express durability dependence for selected cutting tools, specifically high speed steel (HSS), cutting ceramic $\left(\mathrm{Al}_{2} \mathrm{O}_{3}\right)$ and sintered carbide $(\mathrm{P} 20+\mathrm{TiN})$.
\end{abstract}

\begin{abstract}
Abstrakt
Trvanlivost řezného nástroje definuje životnost tohoto řezného nástroje a určuje jeho vhodnost pro vybrané technologické operace. Technické vědy definují mnoho různých faktorů, které mohou být příčinou nižší životnosti řezného nástroje. Některé druhy řezných materiálů jsou definovány pomocí popisů v normách ISO, některé typy prostřednictvím katalogů od výrobce. Existuje mnoho druhů řezných materiálů, jejichž vlastnosti nebyly definovány přesně podle normy a jejich vlastnosti musí být definovány experimentálně. Existuje domněnka, že popisy v normách ISO nejsou správné a tyto standardy by měly být přezkoumány a ověřeny, protože tato skutečnost musí být potvrzena nebo vyvrácena. Přesnost a úplnost technické normy ISO je velmi důležitou součástí kvalitní výroby. Pouze správné normy ISO mohou být použity jako instrukce, nebo nástroj pro výrobní process ve firmě. Tento článek popisuje postup, jak definovat a analyticky vyjádřit závislost trvanlivosti u vybraných řezných nástrojů, konkrétně nástroje z rychlořezné oceli (HSS), řezné keramiky $\left(\mathrm{Al}_{2} \mathrm{O}_{3}\right)$ a slinutého karbidu $(\mathrm{P} 20+\mathrm{TiN})$.
\end{abstract}

\section{INTRODUCTION}

Problems of reliability and life tools are in the present very current. A lot of manufacturer of cutting tools determined durability of cutting tool only on the assumption or presumption. Problematic of tool durability and its lifetime is defined in standard ISO 3685. This standard describes how to define $T-v_{\mathrm{c}}$ dependence for different cutting materials by means of machining longterm test method. The base of this test is turning workpieces on the equal diameter. [9]

* Ján DUPLÁK, Michal HATALA, FVT TU Košice with seat in Prešov, Department of Manufacturing Technologies, Slovakia 
Turning is the most basic process in machining, because it forms $30 \%$ from all technologies of machining. In turning there are many types used of cutting tools made of different materials. Some of these materials are high speed steel, cutting ceramic, sintered carbide. [1, 7]

High speed steel (HSS) is a subset of tool steels, usually used in tool bits and cutting tools. It is superior to the older high carbon steel tools used extensively through the 1940s in that it can withstand higher temperatures without losing its hardness. [3]

Sintered carbide is unique combination of strength, hardness and toughness satisfies the most demanding applications. [5]

Ceramic cutting tools have been in use for approximately 90 years. However, as new cutting tools were developed, new materials that demanded even more rigorous machining requirements were also developed. [2, 4]

\section{BASIC THEORETICAL SOURCES OF DURABILITY DEPENDENCE}

Graphics dependence $V B=\mathrm{f}\left(\tau_{\mathrm{s}}\right)$ for different cutting speeds was described with Frederick Winslow Taylor in 1906. Taylor defined that the criterion of blunting was the same for all curves $V B_{\mathrm{k}}$. Dependences that are described by Taylor are relevant only for high speed steel, because in that time high speed steel was only available for Taylor experiments. [6]

Knowledge defined by Taylor is used in standard ISO 3685. Standard ISO 3685 obtains tests of durability of cutting tools for workpieces made of steel and cast iron. This standard includes only cutting tools made of high cutting steel, sintered carbide and cutting ceramic. Standard is valid only for conditions, when the criterion of durability is defined as tool wear. ${ }^{8}$

\section{OUTPUTS OF STANDARD ISO 3685 ANALYSIS}

The standard ISO 3685 describes for all cutting materials common $T$ - $v_{\mathrm{c}}$ dependence. Current valid relation of $T-v_{\mathrm{c}}$ dependence is described by Taylor formed basics of standard ISO 3685. $T-v_{\mathrm{c}}$ dependence was designed according to Taylor in logarithmic scale. ${ }^{6}$

Very significant problem in standard ISO 3685 is evaluation of results. Characteristics and dependences for all cutting materials are same. ${ }^{9}$

\section{CONCLUSIONS FROM ANALYSIS OF STANDARD ISO 3685}

Standard ISO 3685 describes more methods for solution of $T-v_{\mathrm{c}}$ dependence. For each method that is described in standard there should be exactly identified procedure for obtaining of tested dependences. Standard ISO 3685 indicates these methods to obtain the results:

- To toggle the line through measured points

(approximation)

- Method of least squares

- Interpolation of dependence into unmeasured field of cutting speeds.

- Guess evaluation

\section{THE DURABILITY ON THE BASED OF $T_{\mathrm{V}}$ - $C$ DEPENDENCE ACCORDING TO STANDARD ISO}

Taylor defined $T-v_{\mathrm{c}}$ dependence according to experiments made with high speed steel. These tests according to standard ISO 3685 are valid for all cutting materials. The standard ISO 3685 contains information about $T-v_{\mathrm{c}}$ dependences for high speed steel, sintered carbide and cutting ceramic. [9] 


\section{MACHINING LONG-TERM TEST METHOD}

Machining long-term test method is essentially only one. Criterion is value of cutting speed and it makes by turning or milling with describes constant cutting parameters, type of cutting tool with defined geometry and graduated cutting speeds to the optimal tip blunting. This test is considered as basic and by this test takes measure objectivity of machinability for others tests. Disadvantage of this test is consumption of workpieces and time consumption.

Description of machining long-term test method:

1) Time measurement process of depreciation on back of tool $V B_{\mathrm{B}}$, for few value of cutting speeds at constant cutting parameters and construction curve of blunting.

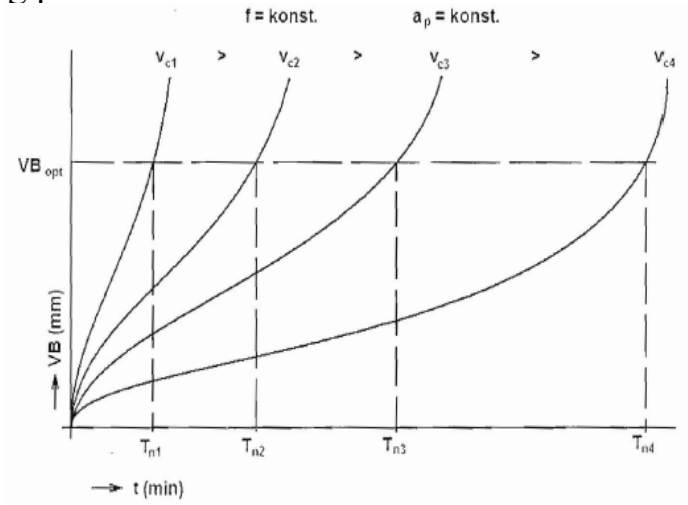

Fig. 1. Curve of blunting for variable cutting speeds.

2) Specification criterion of depreciation $V B_{\text {opt }}$ and determination tip durability for each cutting speed.

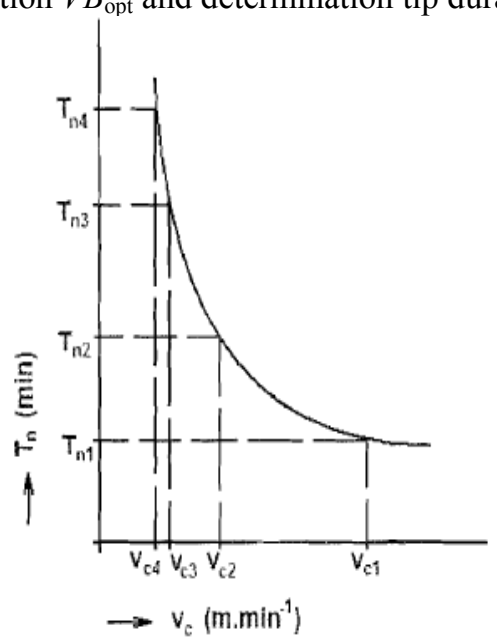

Fig. 2. Determination of particular durability by the criterion of depreciation.

3) Construction $T_{\mathrm{n}} \mathrm{=} \mathrm{f}\left(v_{\mathrm{c}}\right)$ dependence in logarithmic scale and determination index of machinability for selected durability under comparison cutting speed tested material and etalon material. 


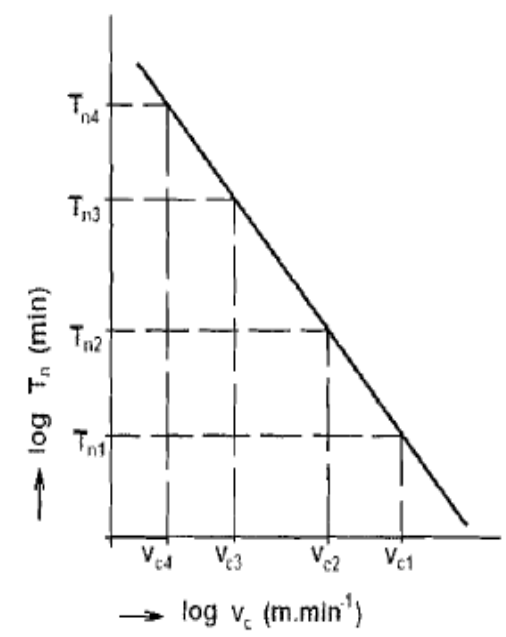

Fig. 3. $T-v_{\mathrm{c}}$ dependence in logarithmic scale.

\section{EXPERIMENTS WITH CUTTING TOOLS}

First very important step, before the actual experiments is specification of technological system. In technological system for these experiments were contained machine - tool - workpiece.

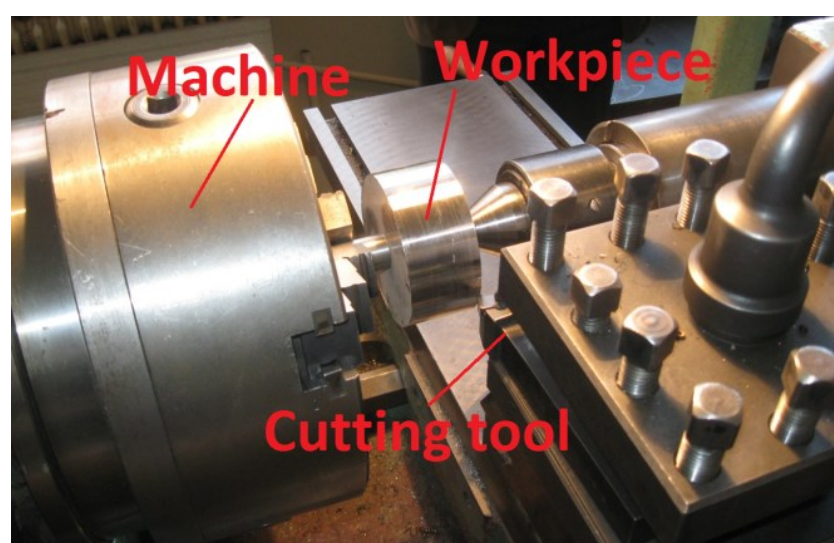

Fig. 4. Technological system for experiments.

Workpieces for experiments are made of steel C45. Material for workpieces is from specific material list with guaranteed chemical structure and mechanical properties.

Table 1. Chemical structure of $\mathrm{C} 45$.

\begin{tabular}{|c|c|c|c|c|c|c|c|}
\hline \multicolumn{7}{|c|}{ Chemical structure of C45 [\%] } \\
\hline $\mathbf{C}$ & $\mathbf{M n}$ & $\mathbf{S i}$ & $\mathbf{C r}$ & $\mathbf{N i}$ & $\mathbf{C u}$ & $\mathbf{P}$ & $\mathbf{S}$ \\
\hline 0.42 & 0.50 & 0.17 & $\max$ & $\max$. & $\max$. & $\max$ & $\max$. \\
-0.50 & - & - & 0.25 & 0.30 & 0.30 & 0.040 & 0.040 \\
& 0.80 & 0.37 & & & & \\
\hline
\end{tabular}


Table 2. Mechanical properties of C45.

\begin{tabular}{|c|c|c|c|c|}
\hline \multicolumn{5}{|c|}{ Mechanical properties of C45 } \\
\hline $\begin{array}{c}\boldsymbol{R}_{\mathbf{e}} \\
{[\mathbf{M P a}]}\end{array}$ & $\begin{array}{c}\boldsymbol{R}_{\mathbf{m}} \\
{[\mathbf{M P a}]}\end{array}$ & $\boldsymbol{A}_{\mathbf{5}}[\%]$ & HB & $\begin{array}{c}\boldsymbol{E} \\
{[\mathbf{G P a}]}\end{array}$ \\
\hline min. 305 & min. 530 & 16 & $\max .225$ & 221 \\
\hline
\end{tabular}

These experiments were made under defined technological conditions. Tool durability was proven with kinetic machining long-term test method. Experiment inputs were workpieces with equal diameters; those were used at turning process. For each cutting speed the diameter should have the same value, because examined material has different consistency in different depth. Experiment was finished once wear criterion was reached.

\section{TECHNOLOGICAL CONDITIONS USED FOR HIGH SPEED STEEL} $\gamma_{0}=-6^{\circ}$

$$
v_{\mathrm{c}}=2-100 \mathrm{~m} \cdot \mathrm{min}^{-1} ; a_{\mathrm{p}}=0.5 \mathrm{~mm} ; f=0.3 \mathrm{~mm} ; r_{\varepsilon}=0.5 \mathrm{~mm} ; \kappa_{\mathrm{r}}=75^{\circ} ; \kappa_{\mathrm{r}}^{\prime}=15^{\circ} ; V B=0.3 \mathrm{~mm} ;
$$

Table 3. Results of $T-v_{\mathrm{c}}$ dependence for HSS.

\begin{tabular}{|c|c|c|c|}
\hline \begin{tabular}{c}
$\boldsymbol{v}_{\mathbf{1}} \cdot \mathbf{m}_{\mathbf{1}} \mathbf{m i n}^{-}$ \\
\hline 2
\end{tabular} & $\boldsymbol{T} \cdot \mathbf{m i n}$ & $\boldsymbol{v}_{\mathbf{c}} \cdot \mathbf{m} \cdot \mathbf{m i n}^{-\mathbf{1}}$ & $\boldsymbol{T} \cdot \mathbf{m i n}$ \\
\hline 2.5 & 105 & 35 & 8 \\
\hline 3.3 & 87 & 41 & 6 \\
\hline 11 & 33 & 52 & 3.3 \\
\hline 13 & 22 & 58 & 2.8 \\
\hline 22 & 21 & 100 & 1.5 \\
\hline 28 & 14 & & 1.2 \\
\hline
\end{tabular}

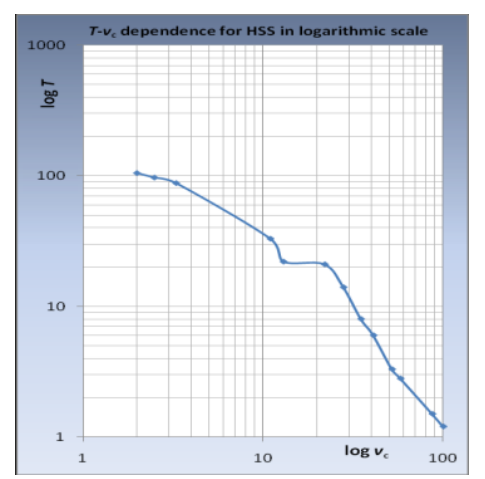

Fig. 5. $T-v_{\mathrm{c}}$ dependence for HSS in logarithmic scale. 
9 TECHNOLOGICAL CONDITIONS USED FOR CUTTING CERAMIC $\left(\mathrm{AL}_{\mathbf{2}} \mathrm{O}_{3}\right)$

$v_{\mathrm{c}}=2-550 \mathrm{~m} \cdot \mathrm{min}^{-1} ; a_{\mathrm{p}}=0.2 \mathrm{~mm} ; f=0.3 \mathrm{~mm} ; r_{\varepsilon}=0.8 \mathrm{~mm} ; \kappa_{\mathrm{r}}=80^{\circ} ; \kappa_{\mathrm{r}}^{\prime}=10^{\circ} ; V B=0.3 \mathrm{~mm} ;$

Table 4. Results of $T-v_{\mathrm{c}}$ dependence for $\mathrm{Al}_{2} \mathrm{O}_{3}$.

\begin{tabular}{|l|l|l|l|}
\hline $\boldsymbol{v}_{\mathbf{c}}, \mathbf{m} \cdot \mathbf{m i n}^{-\mathbf{1}}$ & $\begin{array}{l}\boldsymbol{T}, \\
\mathbf{m i n}\end{array}$ & $\boldsymbol{v}_{\mathbf{c}}, \mathbf{m} \cdot \mathbf{m i n}^{-\mathbf{1}}$ & $\boldsymbol{T}, \mathbf{m i n}$ \\
\hline 2 & 55 & 139 & 25.5 \\
\hline 8 & 35 & 147 & 25 \\
\hline 12 & 22 & 153 & 21 \\
\hline 16 & 19 & 158 & 20.7 \\
\hline 17.5 & 18 & 188 & 14 \\
\hline 22 & 16.8 & 225 & 10 \\
\hline 35 & 15 & 235 & 9.5 \\
\hline 49 & 26.5 & 253 & 9 \\
\hline 51 & 27 & 268 & 8.9 \\
\hline 55 & 27.5 & 380 & 7.2 \\
\hline 85 & 28.3 & 440 & 6.3 \\
\hline 100 & 29.5 & 510 & 6 \\
\hline 130 & 27 & 530 & 5.8 \\
\hline 136 & 26 & 550 & 5 \\
\hline
\end{tabular}

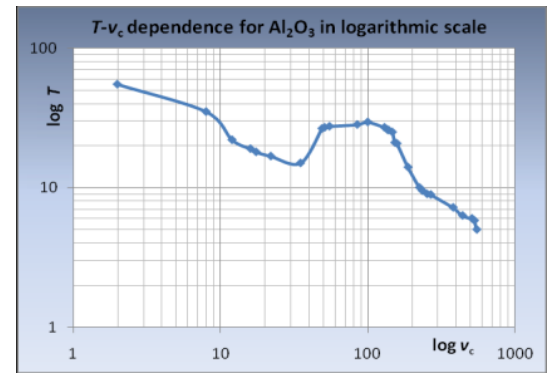

Fig. 6. $T-v_{\mathrm{c}}$ dependence for $\mathrm{Al}_{2} \mathrm{O}_{3}$ in logarithmic scale.

\section{TECHNOLOGICAL CONDITIONS USED FOR SINTERED} CARBIDE (P20+TIN)

$v_{\mathrm{c}}=5-350 \mathrm{~m} \cdot \mathrm{min}^{-1} ; a_{\mathrm{p}}=0,2 \mathrm{~mm} ; f=0.3 \mathrm{~mm} ; \quad r_{\varepsilon}=0.8 \mathrm{~mm} ; \kappa_{\mathrm{r}}=80^{\circ} ; \kappa_{\mathrm{r}}^{\prime}=10^{\circ} ;$ $V B=0.3 \mathrm{~mm}$;

Table. 5. Results of $T-v_{\mathrm{c}}$ dependence for P20+TiN

\begin{tabular}{|c|c|l|l|}
\hline $\boldsymbol{v}_{\mathbf{c}}, \mathbf{m} \cdot \mathbf{m i n}^{-\mathbf{1}}$ & $\boldsymbol{T}, \mathbf{m i n}$ & $\boldsymbol{v}_{\mathbf{c}}, \mathbf{m} \cdot \mathbf{m i n}^{-1}$ & $\boldsymbol{T}, \mathbf{m i n}$ \\
\hline 5 & 250 & 93 & 230 \\
\hline 8 & 210 & 105 & 215 \\
\hline 10 & 125 & 112 & 204 \\
\hline 13 & 86 & 125 & 148 \\
\hline 25 & 70 & 137 & 64 \\
\hline 39 & 118 & 205 & 42 \\
\hline 46 & 130 & 250 & 23 \\
\hline 65 & 180 & 310 & 15 \\
\hline 72 & 205 & 350 & 13 \\
\hline
\end{tabular}




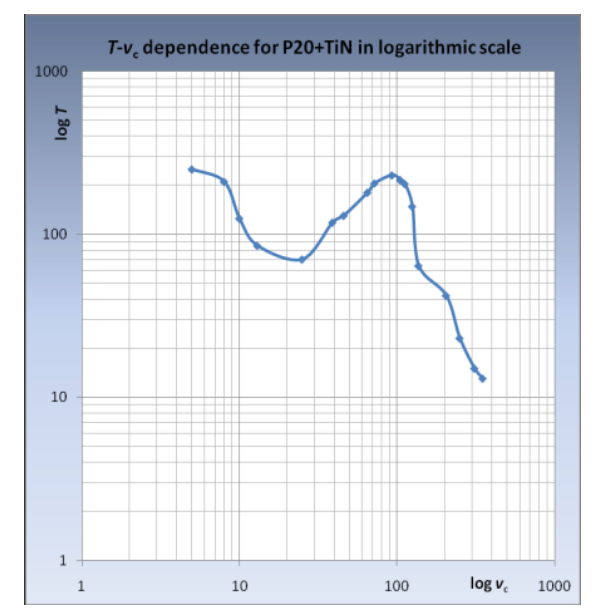

Fig. 7. $T-v_{\mathrm{c}}$ dependence for $\mathrm{P} 20+\mathrm{TiN}$ in logarithmic scale.

\section{CONCLUSIONS}

Very important part of quality production in engineering companies is quality tool. Tools with listed and described properties are indispensable in the production. The most important part when develop the tools is its material. Material for cutting tools defines theirs machining properties. Testing properties of those materials are very important, because their properties may be different than properties defined in standards ISO. Cutting speed, cutting depth and feed of tool is possible calculate according to defined technological conditions, but durability tool as was written in introduction is necessary to evaluate according to realized experiments, or to compare with standard ISO. In this article are described tests for cutting materials made of high speed steel, cutting ceramic $\left(\mathrm{Al}_{2} \mathrm{O}_{3}\right)$ and sintered carbide $(\mathrm{P} 20+\mathrm{TiN})$. Cutting properties of these materials are described in ISO 3685. Defined cutting plates were used for experiments under accurately determined technological conditions. Following picture shows differences between $T-v_{\mathrm{c}}$ dependence from standard ISO 3685 and $T-v_{\mathrm{c}}$ dependencies from experiments results.

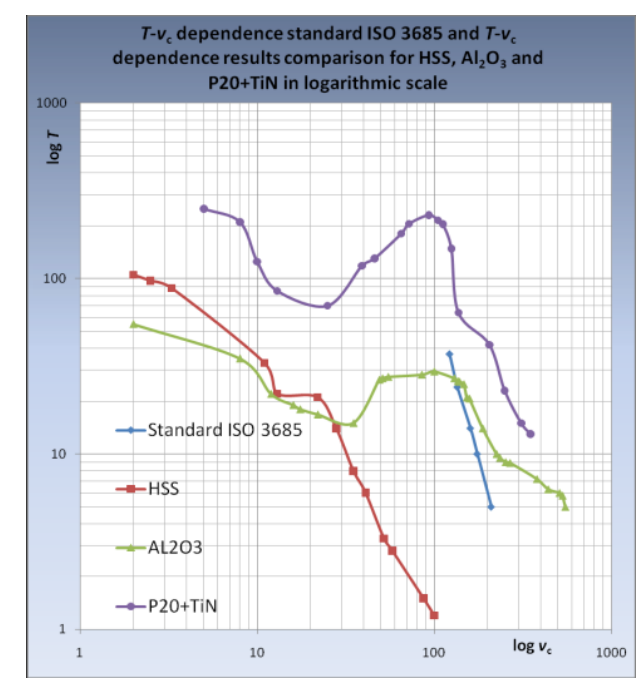

Fig. 8. Standard ISO $3685 T-v_{\mathrm{c}}$ dependence and $T-v_{\mathrm{c}}$ dependencies from experiments comparison. 
Difference between ISO 3685 and $T-v_{\mathrm{c}}$ dependence from results of experiments is appreciable as graphical evidenced on figure 8. These dependencies are defined on the base instructions described in ISO 3685 that was defined according to Taylor. Taylor defined $T-v_{\mathrm{c}}$ dependence on the base of experiments with tools made of high speed steel and all this problematic he described as Taylor's formula for tool durability. Others materials described in ISO have different chemical structure and mechanical properties, so isn't possible to describe those materials by means of $T-v_{\mathrm{c}}$ dependence from ISO 3685, because ISO 3685 is valid only for high speed steel. Deeper exploration of $T-v_{\mathrm{c}}$ dependence defined in ISO 3685 is very important. Experiments show differences with ISO 3685 and conformity is only with $T-v_{\mathrm{c}}$ dependence for high speed steel and then only in a defined set of cutting speeds.

\section{REFERENCES}

[1] E. Isakov. Cutting Data for turning of steel. 28 (2009) 173.

[2] E.D. Whitney. Ceramic Cutting Tools. 30 (1994) 245.

[3] I. Kažimír, J. Beňo. Theory of machining. 5 (1989) 130.

[4] J. R. Davis. Materials - ASM Specialty Handbook. 75 (1998) 389.

[5] J. T. Black, R. A. Kohser. Degarmo's Materials \& Processes. 23 (2007) 886.

[6] K. Vasilko. Theory and practice of splinter machining. 21 (2009) 151.

[7] P. Michalik, J. Zajac. Intelligently programming of holes machining. 18 (2010) 63-65.

[8] R. Čep, J. Kratochvil, V. Vrba, M. Hatala. Using of intendant techniques to determination of ceramic materials mechanical properties. 18 (2007) $23-25$.

[9] R. F. Bunshah. Handbook of hard coatings. 48 (2001) 320.

STN ISO 3685: Tool-life testing with single-point turning tools. 19 (1999) 30. 